\title{
PEMANFAATAN SISA PANEN TANAMAN PISANG SEBAGAI PENGGANTI RUMPUT DALAM PAKAN KOMPLIT BERBENTUK PELET TERHADAP PERFORMANS DOMBA LOKAL JANTAN LEPAS SAPIH
}

\author{
(Utilization of Pelleting Banana Crop Residu to Substitute Grass on Performances \\ of Weaning Male Local Sheep)
}

\author{
Benny Syah Braymana ${ }^{1}$, Iskandar Sembiring ${ }^{2}$ dan Usman Budi ${ }^{2}$ \\ 1. Mahasiswa Program Studi Peternakan Fakultas Pertanian Universitas Sumatera Utara \\ 2. Staf Pengajar Program Studi Peternakan Fakultas Pertanian Universitas Sumatera Utara
}

\begin{abstract}
The research was conducted in the Animal Biology Laboratory, Animal Husbandry Department, Agriculture Faculty, University of Sumatera Utara started from July to November 2013. This aims of research was to determine utilization of pelleting banana crop residu to substitute grass on feed intake, body weight gain and feed conversion ratio of weaning male local sheep. Twenty male local sheeps were used with initial body weight 8,63 $\pm 2,06 \mathrm{~kg} / \mathrm{head}$ and divided into four treatments and five replications using completely randomized design as design experiment. The treatments were analyzed level substitution of grass with banana crop residu i;e 0\% (P0), 33\% (P1), 67\% (P2), $100 \%$ (P3). Variables were observed consist of feed intake, body weight gain and feed conversion ratio. The results showed that utilization of pelleting banana crop residu to substitute grass were not significantly different effect $(P>0,05)$ on feed intake, body weight gain and feed conversion ratio. Feed intake (g/head/day) for treatments $P 0$; P1; P2; P3 were 325,32; 369,24; 369,91; 345,36, respetively, while for body weight gain (g/head/day) were 39,45; 51,$24 ; 59,70 ; 55,32$, and for feed conversion ratio 11,$74 ; 7,63 ; 6,32 ; 7,11$, respectively. It is concluded that pelleting banana crop residu could substitute grass as much as $100 \%$.
\end{abstract}

Keywords : Performance, Weaning male local sheep, Banana crop residu

\begin{abstract}
ABSTRAK
Penelitian ini dilaksanakan di Laboratorium Biologi Ternak Fakultas Pertanian Universitas Sumatera Utara mulai bulan Juli sampai November 2013. Penelitian ini bertujuan untuk mengetahui pengaruh pemberian sisa panen tanaman pisang sebagai pengganti rumput dalam pakan komplit berbentuk pelet terhadap konsumsi pakan, pertambahan bobot badan dan konversi pakan domba lokal jantan lepas sapih. Domba lokal jantan yang digunakan sebanyak 20 ekor dengan kisaran bobot badan awal 8,63 $\pm 2,06 \mathrm{~kg}$ yang dibagi ke dalam empat perlakuan dan lima ulangan dengan menggunakan rancangan acak lengkap sebagai rancangan percobaan. Perlakuan yang digunakan meliputi penggantian rumput dengan sisa panen tanaman pisang sebesar 0\% (P0), 33\% (P1), 67\% (P2), 100\% (P3). Parameter yang diteliti yaitu konsumsi pakan, pertambahan bobot badan dan konversi pakan. Hasil penelitian menunjukkan bahwa pemanfaatan sisa panen tanaman pisang sebagai pengganti rumput dalam pakan komplit berbentuk pelet tidak berpengaruh nyata $(\mathrm{P}>0,05)$ terhadap konsumsi pakan, pertambahan bobot badan dan konversi pakan. Hasil dari perlakuan P0; P1; P2; P3 terhadap konsumsi pakan (g/ekor/hari) adalah 325,32; 369,24; 369,91; 345,36, pertambahan bobot badan (g/ekor/hari) adalah 39,45; 51,24; 59,70; 55,32 dan konversi pakan adalah 11,74; 7,$63 ; 6,32 ; 7,11$ domba lokal jantan lepas sapih. Kesimpulan dari hasil penelitian ini adalah sisa panen tanaman pisang dapat menggantikan keberadaan rumput sebanyak $100 \%$ dari komposisi pakan komplit berbentuk pelet.
\end{abstract}

Kata kunci : Performans, Domba lokal jantan lepas sapih, Sisa panen tanaman pisang. 


\section{PENDAHULUAN}

Kebutuhan protein hewani masyarakat Indonesia terus meningkat seiring dengan pertambahan penduduk dan meningkatnya kesadaran masyarakat akan pentingnya zat gizi. Sehingga peternakan merupakan sektor yang berperan sangat penting dalam penyediaan kebutuhan pangan khususnya kebutuhan protein hewani tersebut.

Secara umum ternak domba mempunyai beberapa keuntungan dilihat dari segi pemeliharaan seperti: cepat berkembang biak dan dapat beranak lebih dari satu ekor dan dapat beranak dua kali setahun, berjalan dengan jarak lebih dekat sehingga lebih mudah dalam pemeliharaan, pemakan rumput, kurang memilih pakan yang diberikan sehingga lebih mudah dalam pemeliharaan, dapat memberikan pupuk kandang dan sebagai sumber keuangan untuk keperluan pertanian atau untuk memenuhi kebutuhan rumah tangga yang mendadak (Tomaszweska et al., 1993).

Domba asli Indonesia adalah domba yang memiliki ekor tipis, populasinya ada di Jawa Barat dan Jawa Tengah sekitar $80 \%$. Domba jantan memiliki tanduk yang kecil sedangkan domba betina tidak memiliki tanduk. Ekor relatif tipis dan kecil. Domba jantan dewasa memiliki bobot badan sekitar 30-40 kg sedangkan bobot badan betina sekitar 15-20 kg (Mulyono, 1998).

Semakin sempitnya lahan dalam sektor peternakan akan memberikan dampak ketersediaan bahan pakan yang dibutuhkan ternak, terutama ternak ruminansia yang bahan makanan utamanya adalah berupa hijauan atau rumput. Untuk mengatasi hal tersebut maka perlu dicari suatu pakan alternatif yang dapat menggantikan rumput sebagai pakan ternak. Salah satunya adalah hasil samping tanaman pisang yang merupakan hasil samping pertanian yang berasal dari tanaman pisang yang biasanya hanya dibiarkan atau dibuang setelah pisang dipanen. Dilihat dari kandungan serat kasar beserta zat-zat pakan yang terdapat di dalamnya, hasil samping tanaman pisang mempunyai potensi untuk dijadikan bahan pakan ternak ruminansia (Wina, 2001).

Usaha tani pisang saat ini dapat menambah pendapatan petani apabila dapat diterapkan penanaman pisang yang secara modern. Penanaman modern secara umum belum diketahui oleh masyarakat, karena kebanyakan masyarakat menanam secara tradisional, maka dengan demikian pemerintah setempat khususnya Dinas Pertanian Sumatera Utara melakukan terobosan dengan adanya penyuluhan pertanian di daerah Kabupaten Deli Serdang khususnya dalam penyuluhan cara penanaman, perawatan atau pemeliharaan dan pemupukan tanaman pisang. Agar dapat 
menghasilkan produksi yang lebih bermutu dan dapat memenuhi permintaan pasar baik lokal maupun luar negeri. Saat ini dikhususkan di daerah Kecamatan STM Hilir Kabupaten Deli Serdang karena merupakan daerah sentra produksi buah pisang yang ada di Sumatera Utara (Dinas Pertanian Provinsi Sumatera Utara, 2008).

Umumnya hasil samping pertanian mempunyai beberapa sifat sebagai berikut: 1). Nilai nutrisi rendah terutama protein dan kecernaannya; 2). Bersifat bulky sehingga biaya angkutan menjadi mahal karena membutuhkan tempat lebih banyak untuk satuan berat tertentu; 3). Kelembabannya tinggi dan menyulitkan penyimpanan; dan 4). Penampilannya yang kurang menyenangkan (Siregar, 1995). Sehingga perlu dilakukan teknologi pembuatan pakan ternak berbentuk pelet. Untuk kedepannya teknologi pelleting dapat menggantikan pengolahan pakan yang hanya berbentuk segar dan tepung.

Keuntungan bentuk pelet selain untuk efisiensi ruang penyimpanan/pengangkutan, juga dapat menghilangkan suasana berdebu, mengurangi sisa pakan, mencegah selektivitas pakan oleh ternak, mengurangi senyawa patogen, menyebabkan pati lebih dapat dicerna, meningkatkan palatabilitas, dan dapat meningkatkan konsumsi pakan dengan waktu yang lebih pendek (Winoswiski, 1995).

Berdasarkan uraian di atas maka penulis tertarik untuk mengetahui sejauh mana pengaruh pemanfaatan sisa panen tanaman pisang sebagai pengganti rumput dalam pakan komplit berbentuk pelet sebagai pakan ternak terhadap konsumsi pakan, pertambahan bobot badan dan konversi pakan domba lokal jantan lepas sapih.

\section{BAHAN DAN METODE PENELITIAN}

\section{Lokasi dan Waktu Penelitian}

Penelitian telah dilaksanakan di Laboratorium Biologi Ternak, Program Studi Peternakan, Fakultas Pertanian, Universitas Sumatera Utara. Berlangsung mulai dari bulan Juli sampai November 2013.

\section{Bahan}

Adapun domba yang digunakan adalah domba lokal jantan lepas sapih sebanyak 20 ekor dengan kisaran bobot badan awal 8,63 $\pm 2,06 \mathrm{~kg}$. Bahan pakan yang diberikan terdiri atas: sisa panen tanaman pisang dan rumput lapangan sebagai hijauan serta konsentrat terdiri atas: dedak padi, bungkil kelapa, molases, urea, garam dan ultra mineral. Bahan pakan dan konsentrat diolah 
menjadi pakan pelet. Obat-obatan seperti obat cacing (kalbazen), anti bloat untuk obat kembung, air minum, desinfektan (rodalon) dan obat tradisional.

\section{Alat}

Kandang terdiri atas kandang individu 20 unit dengan ukuran 1 x $0,5 \mathrm{~m}^{2}$ beserta perlengkapannya, ember sebanyak 20 buah sebagai tempat pakan dan 20 buah tempat minum, timbangan untuk menimbang bobot hidup berkapasitas $40 \mathrm{~kg}$ dengan kepekaan $10 \mathrm{~g}$, timbangan berkapasitas $5 \mathrm{~kg}$ dengan kepekaan $1 \mathrm{~g}$ untuk menimbang pakan, terpal plastik untuk mencampur dan menjemur bahan pakan, karung plastik sebagai tempat pakan, alat penerangan, grinder untuk menghaluskan bahan pakan, mesin pelleting untuk mencetak pakan pelet, alat tulis untuk mencatat data selama penelitian, alat pembersih kandang dan termometer untuk mengetahui suhu di dalam dan di luar kandang.

\section{Metode Penelitian}

Rancangan percobaan yang digunakan dalam penelitian ini adalah secara experimental dengan menggunakan rancangan acak lengkap (RAL) dengan 4 perlakuan dan 5 ulangan. Adapun perlakuan tersebut sebagai berikut:

P0: Pakan pelet yang mengandung (60\% rumput $+40 \%$ bahan lain)

P1: Pakan pelet yang mengandung (20\% sisa panen tanaman pisang $+40 \%$ rumput $+40 \%$ bahan lain)

P2: Pakan pelet yang mengandung (40\% sisa panen tanaman pisang $+20 \%$ rumput $+40 \%$ bahan lain)

P3: Pakan pelet yang mengandung (60\% sisa panen tanaman pisang $+40 \%$ bahan lain)

Tabel 1. Kandungan nilai nutrisi bahan pakan penyusun pakan komplit domba

\begin{tabular}{lcccccc}
\multicolumn{1}{c}{ Bahan } & BK & K.Abu & PK & LK & SK & TDN \\
\hline S.P.T.P. $^{\text {a }}$ & 92,39 & 15,45 & $10,59^{\mathrm{g}}$ & 3,94 & $28,21^{\mathrm{g}}$ & 58,51 \\
Rumput Lapangan $^{\mathrm{b}}$ & 27,91 & 8,89 & 10,62 & 8,33 & 23,25 & 68,62 \\
Dedak Padic $^{\mathrm{c}}$ & 89,6 & & 13,80 & 7,20 & 8,00 & 67,00 \\
Bungkil Kelapa $^{\mathrm{d}}$ & 84,40 & 5,18 & 21,00 & 1,80 & 15,00 & 79,00 \\
Molases $^{\mathrm{e}}$ & 92,6 & & 4,00 & 0,08 & 0,38 & 81,00 \\
Urea $^{\mathrm{f}}$ & & & 281 & & & \\
\hline
\end{tabular}

Keterangan: S.P.T.P: Sisa Panen Tanaman Pisang

Sumber: a. Laboratorium BP3 Loka Penelitian Kambing Potong Sei Putih-Galang (2013)

b. Laboratorium IP2TP Sei Putih-Galang (1997)

c. Laboratorium Ilmu Nutrisi dan Pakan Ternak Departemen Peternakan FP USU (2005)

d. Laboratorium Ilmu Nutrisi dan Pakan Ternak Departemen Peternakan FP USU (2005)

e. Laboratorium Ilmu Makanan Ternak Program Studi Peternakan, FP USU (2000)

f. Belasco (1954), g. Sucofindo (2013) 
Tabel 2. Susunan bahan pakan komplit selama penelitian

\begin{tabular}{lcccc}
\hline \multirow{2}{*}{ Bahan Pakan } & \multicolumn{5}{c}{ Perlakuan } \\
\cline { 2 - 5 } & P0 & P1 & P2 & P3 \\
\hline S.P.T.P & 0 & 20 & 40 & 60 \\
Rumput Lapangan & 60 & 40 & 20 & 0 \\
Dedak Padi & 26 & 26 & 26 & 26 \\
Bungkil Kelapa & 6 & 6 & 6 & 6 \\
Molases & 5 & 5 & 5 & 5 \\
Urea & 1 & 1 & 1 & 1 \\
Garam & 1 & 1 & 1 & 1 \\
Ultra Mineral & 1 & 1 & 1 & 1 \\
\hline Total & 100 & 100 & 100 & 100 \\
\hline Kandungan Nutrisi & & & & \\
PK & 14,23 & 14,22 & 14,22 & 14,21 \\
LK & 6,98 & 6,10 & 5,23 & 4,35 \\
SK & 16,95 & 17,94 & 18,93 & 19,93 \\
TDN & 67,38 & 65,36 & 63,34 & 61,32 \\
\hline
\end{tabular}

Keterangan: S.P.T.P: Sisa Panen Tanaman Pisang

Menurut Hanafiah (2003) model linear untuk rancangan acak lengkap (RAL) adalah :

$$
\mathbf{Y i j}=\boldsymbol{\mu}+\boldsymbol{\alpha} \mathbf{i}+\varepsilon \mathbf{i j}
$$

Dimana: $\quad$ Yij $=$ Respon atau nilai pengamatan dari perlakuan ke-i ulangan ke-j

$\mu \quad=$ Nilai tengah umum

$\alpha \mathrm{i}=$ Pengaruh perlakuan ke-i

$\varepsilon \mathrm{ij}=$ Pengaruh galat (Experimental error) perlakuan ke-I pada ulangan ke-j

\section{Analisis Data}

Untuk mengetahui pengaruh perlakuan terhadap parameter yang diukur, data yang diperoleh dianalisis dengan sidik ragam dan dilanjutkan dengan uji Beda Nyata Terkecil (BNT) (Steel dan Torrie, 1993).

\section{Parameter yang diamati}

\section{Konsumsi Pakan}

Konsumsi pakan dihitung setiap satu hari satu malam (24 jam). Data konsumsi pakan diperoleh dengan cara melakukan penimbangan pakan yang diberikan pada pagi hari kemudian dikurangkan dengan penimbangan sisa pakan yang dilakukan pada pagi hari berikutnya. Konsumsi pakan dapat dirumuskan sebagai berikut: Konsumsi Pakan $(B K)=$ Pakan yang diberikan (g)-Pakan yang sisa (g) (Sodiq dan Abidin, 2002). 


\section{Pertambahan Bobot Badan Harian (PBBH)}

Pertambahan bobot badan dihitung dengan cara membagi selisih bobot badan (bobot badan akhir - bobot badan awal) dengan jumlah hari pengamatan pertumbuhan bobot badan yang dihitung setiap satu minggu sekali, dinyatakan dalam gram per ekor per hari. Pertambahan bobot badan harian dirumuskan sebagai berikut:

$\mathrm{PBBH}=\frac{\text { Bobot Badan Akhir-Bobot Badan Awal (g/ekor) }}{\text { Jumlah hari pengamatan (hari) }}$

(Sodiq dan Abidin, 2002).

\section{Konversi Pakan}

Konversi pakan dihitung dengan cara membagi banyaknya pakan yang dikonsumsi per ekor per hari dengan produksi pertambahan bobot badan per ekor per hari. Konversi pakan dirumuskan sebagai berikut:

$$
\text { Konversi Pakan }=\frac{\text { pakan yang dikonsumsi }(\mathrm{g} / \mathrm{har})}{\mathrm{PBBH}(\mathrm{g} / \mathrm{hari})}
$$

(Sodiq dan Abidin, 2002).

\section{HASIL DAN PEMBAHASAN}

Rataan dari ketiga parameter yaitu: konsumsi pakan, pertambahan bobot badan dan konversi pakan hasil penelitian dapat dilihat pada Tabel 3.

Tabel 3. Rekapitulasi Rataan Hasil Penelitian

\begin{tabular}{lccc}
\hline Perlakuan & $\begin{array}{c}\text { Konsumsi Pakan } \\
(\mathrm{g} / \text { /ekor/hari) }\end{array}$ & $\begin{array}{c}\text { Pertambahan bobot } \\
\text { badan (g/ekor/hari) }\end{array}$ & Konversi pakan \\
\hline P0 & $325,32^{\text {th }} \pm 59,18$ & $39,45^{\text {tn }} \pm 26,60$ & $11,74^{\text {tn }} \pm 7,22$ \\
P1 & $369,24^{\text {tn }} \pm 69,73$ & $51,24^{\text {tn }} \pm 19,78$ & $7,63^{\text {tn }} \pm 1,39$ \\
P2 & $369,91^{\text {tn }} \pm 35,19$ & $59,70^{\text {tn }} \pm 10,41$ & $6,32^{\text {tn }} \pm 1,06$ \\
P3 & $345,36^{\text {tn }} \pm 47,47$ & $55,32^{\text {tn }} \pm 24,13$ & $7,11^{\text {tn }} \pm 2,54$ \\
\hline Rataan & 352,46 & 51,43 & 8,20 \\
\hline
\end{tabular}

Ket. tn = tidak berbeda nyata

\section{Konsumsi Pakan dalam Bahan Kering (BK)}

Berdasarkan pada Tabel 3 dapat dilihat bahwa rataan konsumsi pakan domba lokal jantan sebesar 352,46 g/ekor/hari. Dari hasil analisis ragam menunjukkan bahwa pemanfaatan sisa 
panen tanaman pisang sebagai pengganti rumput dalam pakan komplit berbentuk pelet terhadap konsumsi pakan domba lokal jantan lepas sapih memberikan pengaruh yang tidak berbeda nyata terhadap konsumsi pakan domba lokal jantan.

Hasil analisis ragam yang menunjukkan tidak adanya perbedaan nyata mengindikasikan bahwa nilai palatabilitas ransum pada tiap perlakuan adalah sama, sehingga ternak dapat mengkonsumsi ransum dalam jumlah yang tidak berbeda. Menurut Parakkasi (1995) bahwa tingkat perbedaan konsumsi dipengaruhi oleh beberapa faktor antara lain faktor ternak (bobot badan, umur, tingkat kecernaan pakan, kualitas pakan dan palatabilitas). Makanan yang berkualitas baik dengan tingkat pemberian pakan yang relatif sama maka tingkat konsumsinya juga tidak berbeda. Hal ini juga diutarakan oleh Bamualim (1988) yang menyatakan bahwa kualitas pakan berpengaruh terhadap konsumsi.

Pengaruh tidak berbeda nyata terhadap konsumsi pakan pelet (dalam bahan kering) disebabkan oleh keseimbangan protein dan energi seperti dinyatakan oleh Parakkasi (1995) bahwa yang menjadi penentu tingkat konsumsi adalah palatabilitas dan zat makanan. Hasil analisis dari keempat perlakuan tidak berbeda nyata, tetapi ada kecenderungan konsumsi pada pakan perlakuan P2 (20\% Rumput + 40\% Sisa Panen Tanaman Pisang + 40\% bahan lain) lebih tinggi dari pada perlakuan yang lain yaitu sebesar 369,91 g/ekor/hari. Pemanfaatan sisa panen tanaman pisang sebagai pengganti rumput dalam pakan komplit berbentuk pelet memberikan pengaruh yang tidak berbeda nyata terhadap konsumsi pakan domba lokal jantan lepas sapih menunjukkan bahwa sisa panen tanaman pisang dapat menggantikan rumput sebanyak $100 \%$.

\section{Pertambahan Bobot Badan}

Berdasarkan pada Tabel 3 dapat dilihat bahwa rataan pertambahan bobot badan domba jantan lokal sebesar 51,43 g/ekor/hari. Dari hasil analisis ragam menunjukkan bahwa pemanfaatan sisa panen tanaman pisang sebagai pengganti rumput dalam pakan komplit berbentuk pelet terhadap pertambahan bobot badan domba lokal jantan lepas sapih memberikan pengaruh yang tidak berbeda nyata terhadap pertambahan bobot badan domba lokal jantan, tetapi ada kecenderungan rataan pertambahan bobot badan tertinggi terdapat pada perlakuan P2 (20\% Rumput $+40 \%$ Sisa Panen Tanaman Pisang $+40 \%$ bahan lain) sebesar 59,70 g/ekor/hari.

Church dan Pond (1998) menyatakan bahwa pertambahan bobot badan yang diperoleh dari percobaan pada ternak merupakan hasil metabolisme zat - zat makanan yang dikonsumsi. Makin baik kualitas pakan yang dikonsumsi ternak akan diikuti dengan pertambahan bobot badan yang 
lebih tinggi. Pemanfaatan sisa panen tanaman pisang sebagai pengganti rumput dalam pakan komplit berbentuk pelet memberikan pengaruh yang tidak berbeda nyata terhadap pertambahan bobot badan domba lokal jantan lepas sapih menunjukkan bahwa sisa panen tanaman pisang dapat menggantikan rumput sebanyak $100 \%$.

\section{Konversi Pakan}

Berdasarkan pada Tabel 3 dapat dilihat bahwa rataan konversi pakan domba lokal jantan sebesar 8,20 dan termasuk hasil yang normal untuk konversi pakan domba. Hal ini sesuai dengan pernyataan Ishida dan Hasan (1993) yang menyatakan bahwa konversi pakan yang normal untuk domba adalah $8,0-10,0$.

Hasil analisis ragam menunjukkan bahwa hasil pemberian pakan dengan menggunakan sisa panen tanaman pisang sebagai pengganti rumput dalam pakan domba lokal jantan terhadap pertumbuhan domba lokal jantan lepas sapih memberikan pengaruh yang tidak berbeda nyata terhadap konversi pakan domba lokal jantan dikarenakan beberapa faktor yakni kualitas pakan, nilai kecernaan dan efisiensi pemanfaatan zat gizi dalam proses metabolisme di dalam jaringan tubuh ternak.

Pond et al. (1995) menyatakan bahwa konversi ransum khususnya ternak ruminansia kecil dipengaruhi oleh kualitas ransum, nilai kecernaan dan efisiensi pemanfaatan zat gizi dalam proses metabolisme di dalam jaringan tubuh ternak. Makin baik kualitas ransum yang dikonsumsi ternak akan diikuti oleh pertambahan bobot badan yang lebih tinggi dan makin efisien penggunaan ransumnya. Serta menurut Nesheim dan Card (1972), faktor yang turut berperan dalam konversi ransum adalah temperatur lingkungan, potensi genetik, nutrisi, kandungan energi dan penyakit.

Hasil analisis dari keempat perlakuan tidak berbeda nyata, tetapi ada kecenderungan konversi pakan pada perlakuan P2 (20\% Rumput $+40 \%$ Sisa Panen Tanaman Pisang $+40 \%$ bahan lain) lebih baik dari pada perlakuan yang lain yaitu sebesar 8,20. Pemanfaatan sisa panen tanaman pisang sebagai pengganti rumput dalam pakan komplit berbentuk pelet memberikan pengaruh yang tidak berbeda nyata terhadap konversi pakan domba lokal jantan lepas sapih menunjukkan bahwa sisa panen tanaman pisang dapat menggantikan rumput sebanyak $100 \%$. 


\section{KESIMPULAN}

Pemanfaatan sisa panen tanaman pisang dapat diberikan pada domba lokal jantan lepas sapih dan dapat menggantikan keberadaan rumput sebanyak 100\% dalam komposisi pakan komplit yang diolah menjadi pelet.

\section{DAFTAR PUSTAKA}

Bamualim, A. 1988. Prosedur dan Parameter dalam Penelitian Pakan Ternak Ruminansia dalam Prinsip Produksi dan Penelitian Peternakan. Kupang.

Belasco, J. C. 1954. New Nitrogen Coumpound for Ruminant a Laboratory Evaluation. J. Anim. Sci. 13 : 601-610.

Church, D.C. dan W.G. Pond. 1998. Basic Animal Nutrition and Feeding. $3^{\text {rd }}$ ed Jhon Willey and Sons. New York.

Dinas Pertanian Provinsi Sumatera Utara. 2008. Data Luas Panen, Produktivitas dan Produksi Tanaman Pisang per Kabupaten di Sumatera Utara. Medan.

Hanafiah, K.A. 2003. Rancangan Percobaan. Fakultas Pertanian, Universitas Sriwijaya. Palembang.

Ishida dan Hasan. 1993. Effects of oil palm frond silase feeding on utilization of diet and meat production in fattening arton. Proc $86^{\text {th }}$ Annual Meeting of Jpn, Zootech, Sci, Soc, Iwate University.

Laboratorium BP3 Loka Penelitian Kambing Potong Sei Putih. 2013. Hasil Analisis Nutrisi Limbah Tanaman Pisang. Galang

Laboratorium IP2TP Sei Putih. 1997. Hasil Analisa Nutrisi Rumput Lapangan. Sei Putih. Galang.

Laboratorium Ilmu Nutrisi dan Pakan Ternak. 2005. Hasil Analisa Nutrisi Dedak Padi. Program Studi Peternakan FP USU. Medan.

Laboratorium Ilmu Nutrisi dan Pakan Ternak. 2005. Hasil Analisa Nutrisi Bungkil Kelapa. Program Studi Peternakan FP USU. Medan.

Laboratorium Ilmu Nutrisi dan Pakan Ternak. 2000. Hasil Analisa Nutrisi Molases. Program Studi Peternakan FP USU. Medan.

Laboratorium Sucofindo. 2013. Hasil Analisa Protein dan Serat Kasar Serbuk Daun, Pelepah dan Batang Pisang. PT. Sucofindo. Medan.

Mulyono, S. 1998. Teknik Pembibitan Kambing dan Domba . Penebar Swadaya. Jakarta.

Nesheim, M. C dan L. E. Card. 1972. Poultry Production. 11th Edition. Lea and Febiger, Philadelphia. p : 235 - 239.

Parakkasi, A. 1995. Ilmu Nutrisi Ruminansia Pedaging. Departemen Ilmu Pakan Ternak, Fakultas Pertanian, IPB. Bogor. 
Pond, W. G., D. D. Church and K. R. Pond. 1995. Basic Animal Nutrition. $4^{\text {th }}$ Edition . John Willey and Sons, Inc. New York. p: $273-289$.

Siregar, S.B. 1995. Pengawetan Pakan Ternak. Penebar Swadaya. Jakarta.

Sodiq, A. dan Z. Abidin. 2002. Penggemukan Domba. Agromedia Pustaka. Jakarta.

Steel R.G.D., dan J.H. Torrie. 1993. Prinsip dan Prosedur Analisis Suatu Pendekatan Biometrika. Edisi Kedua. Penerbit PT. Gramedia. Jakarta.

Tomaszweska, M.W., I.M. Mastika, A. Djajanegara, S. Gardiner dan T.R. Wiradarya. 1993. Produksi Kambing dan Domba di Indonesia. Universitas Sebelas Maret.

Wina, E. 2001. Tanaman Pisang Sebagai Pakan Ternak Ruminansia. Balai Penelitian Ternak. Bogor.

Winoswiski, T.S. 1995. Pellet Quality in Animal Feeds. Ligno Tech USA, Inc. wisconsin. Pp. 1-5. 